\title{
Transatlantica
}

Revue d'études américaines. American Studies Journal

\section{Serial Production, Serial Photography, and the Writing of History in Three Farmers on Their Way to a Dance}

\section{Flora Valadié}

\section{(2) OpenEdition Journals}

Édition électronique

URL : https://journals.openedition.org/transatlantica/4642

DOI : $10.4000 /$ transatlantica.4642

ISSN : 1765-2766

Éditeur

Association française d'Etudes Américaines (AFEA)

\section{Référence électronique}

Flora Valadié, "Serial Production, Serial Photography, and the Writing of History in Three Farmers on Their Way to a Dance », Transatlantica [En ligne], 2 | 2009, mis en ligne le 07 février 2010, consulté le 01 février 2023. URL : http://journals.openedition.org/transatlantica/4642 ; DOI : https://doi.org/10.4000/ transatlantica.4642

Ce document a été généré automatiquement le 1 février 2023.

\section{(c) (i) () $\Theta$}

Creative Commons - Attribution - Pas d'Utilisation Commerciale - Pas de Modification 4.0 International - CC BY-NC-ND 4.0

https://creativecommons.org/licenses/by-nc-nd/4.0/ 


\title{
Serial Production, Serial Photography, and the Writing of History in Three Farmers on Their Way to a Dance
}

\author{
Flora Valadié
}

1 In Three Farmers on Their Way to a Dance, published in 1985, Richard Powers delves into the tectonic impact of artistic revelations as he weaves together three narratives that never exactly connect, but echo one another in multiple ways. The book starts with an aesthetic shock: a first-person narrator comes face to face with August Sander's 1914 photograph, Three Farmers on Their Way to a Dance, which triggers a historical and personal quest about the origins of this picture. The second strand traces the picaresque itineraries of the three farmers themselves, as their tribulations take them through the muddled beginnings of a new era. The last tier is the story of Peter Mays, a contemporary Boston-based computer journalist, whose routine collapses when he catches a glimpse of a mesmerizing redhead resembling Sarah Bernhardt.

2 The motif of the series underlies all three narrative braids, since most of the characters are, at some point, taken in obsessive quests and compulsive repetitions. The paradigm coalesces around two poles: Henry Ford and August Sander. Sander was a German photographer of the beginning of the twentieth century who used photographic series as a way to document life in Weimar Germany: he gathered more than 600 portraits in a project he called "Man of the Twentieth Century," in which he attempted to draw a perfect physiognomic map of his contemporaries. The project gave birth to a pictorial survey of class structures in Germany, Face of our Time, in which Sander displayed 60 of his photographs. According to Olivier Lugon, Sander thought of his work as both a rejection of Expressionism, but also, eventually, of Neue Sachlichkeit (New Objectivity). Along with other critics of Neue Sachlichkeit, the photographer reproached the movement with losing sight of general architectures and global meanings in the name of a supposedly objective description of details ${ }^{1}$. In the early 1920s, Sander joined the 
Group of Progressive Artists, led by Marxist painters Franz Wilhelm Seiwert and Heinrich Hoerle. One of the tenets of the group was to do away with a bourgeois conception of art in which the artifact is but the expression of an individual conscience. The photographic series thus appeared as a form particularly apt to try and find an anonymous, collective voice that would go beyond individual expression; Sander would therefore create a work whose structure would attempt to reveal the structure of society. The form of the series was also a way to meet criteria of contextualization and systematization that Neue Sachlichkeit dismissed. Olivier Lugon evokes the series of photographers Karl Blossfeldt and Robert Petschow as examples of this new documentary trend: against the risk of dispersion incurred by Neue Sachlichkeit, the photographic series appears as an all-inclusive tool whose final goal is knowledge of structures.

With constant references to Henry Ford, August Sander and Walter Benjamin ${ }^{2}$, Powers confirms the status of the series as harbinger of modernism. Further than being a motif, the series tells a story of its own: far from being only an endless repetition of details, it bears a narrative dimension as it necessarily unfolds in time, it is also made of variations, and has a specific mode of composition. The series by Ford and Sander become the metaphor for the fictions both of them build about history. Ford's series of Model Ts delineate continuous human and technological progress (the patient addition of elements leads to a perfect object, that will be in turns reproduced endlessly), while Sander uses the model of the series in his own medium as the best way to explore the world through the repetition and alteration of a motif, that of the portrait. While Ford's series charted the course of progress, Sander's serial presentation of his work undermines such meliorism, as he rejects it as a beautification of reality. Yet Powers suggests that Sander's claim to a strict adherence to truth turns out to be another obvious form of fiction, and lays bare the workings of Sander's constructed neutrality in his recording of history.

4 The recurrence of the series allows Powers to propose an aesthetic that weds history with fiction: though vindicated by Ford and Sander as a perfectly scientific model, the series proves to be the means by which the industrialist and the photographer evolve a myth of their own. Through the paradigm of the series, Powers thus acknowledges the necessity of fiction in the building of a cognitive discourse on the past, but substitutes an aesthetic of intersecting planes for the linear model of the series. The historical event, just like the artifact, is to be perceived in terms of solid geometry, a dimension of which is the viewer's perception of past events and artifacts. I intend to show how an apparently scientific model, the series, is explored by Powers as a means to build fictions about history, and in what ways Three Farmers offers a possible step out of the series by viewing history and art in three dimensions rather than two.

\section{The Fiction of Positivism}

During his visit to the Detroit Institute of Arts, P. (the first-person narrator of the novel) examines a fresco by Diego Rivera glorifying, though in an ambiguous way, the assembly-line, which P. calls "the ultimate social accomplishment, a self-reproducing work of art, precise, brilliant, and hard as steel" (14). P. calls Ford's assembly line, "a machine not of retrospect but of revolutions per minute" (117). Ford's serial production tells us about his vision of history: the past is to be forsaken, only the future must be 
taken into account, and continuous progress is the tale told by the assembly-line, the climax of which is the Model T, cheap, accessible, democratic. Mass production is therefore aimed at satisfying the growing needs of individuals, and the series itself turns out to embody the expansion of the individual, which is instantiated by another series related to Ford in the novel. Peter Mays discovers he has inherited from one of his ancestors a sum of money in coins minted by Ford. The penny, instead of bearing Lincoln's face, bears the effigy of Ford, and the motto "Help The Other Fellow" has replaced "In God We Trust." The model of altruism proposed here is, again, essentially individual: Ford sees himself as a liberator who, thanks to serial production, has allowed masses of individuals to get a car, minimum wage and a forty-hour work week. His series of coins embodies the endless multiplication of the individual. Adolphe, one of the three farmers photographed by Sander, evokes the religious dimension of the mechanical reproduction characteristic of the new era: "The new forms of mechanical reproduction seemed to Adolphe further commandments to go forth and multiply, go and love the image of others as yourself" (228).

6 Ford's minting his own series of coins bears witness to his megalomania (he is, in a way, a "self-reproduced work of art"), but also to a vision of history as made by a handful of individuals like himself: as a great man, he is a landmark in history and thus deserves a coin bearing his effigy, just like Lincoln. According to the narrator, Ford thus turns out to be the direct heir of Thomas Carlyle's conception of history, in which great men hold sway over the masses and shape the course of history thanks to their individual genius and charisma. This belief in the Great Man theory is exemplified by the episode of Ford's Peace Ship, thus related by the narrator:

Ford's solution to end the war was nothing if not simple. Fill a large ship full of celebrities, dignitaries, and common folk, and sail it-the first ever "missile for peace"-at the continent of Europe. Once there, the party could serve as mediating forum for "continuous negotiation," where the belligerents could work out their grievances civilly. This ship would be organized and funded by private individuals. No nation, state, or collective organization could give it official recognition. (118)

7 History, in Ford's view, thus appears as a litany of individual acts performed by Great Men who, like himself, are entrusted with the task of improving the lot of the individual. Ford's series of cars and series of coins tell, on the one hand, the fiction of continuous progress, and on the other suggest that such historical progress requires the agency of great men to follow its course. Such a vision of history is dismissed by the narrator as "simple" (the second sentence sounds like a cooking recipe), nay simplistic, and belongs to the realm of the conditional and of a dreamt-up linearity in which tomorrow will always solve the problems of today. The narrator sheds light on the paradoxes of Ford's behaviour: after the fated idea of the Peace Ship, he became one of America's most prosperous armourers, thus contradicting his previous pacifism. The narrator ascribes this reversal to "frustrated narcissism" and asserts that "his altruism easily seems the work of a man caught in the drain of self-love" (126). The failure of the Peace Ship and Ford's complete turnaround thus puncture the myth that Ford's series metaphorise: great men don't necessarily lead humanity towards a better future, and further than that great men themselves are subject to vagaries of behaviour since selfappointed pacifists can suddenly turn into war profiteers. Ford's own paradoxes thus 
belie his vision of history as a succession of events dependent on individual decisions and necessarily oriented towards a better future as inadequate and ideological.

\section{“Face of Our Time": Sander's felix culpa}

8 Like Ford, August Sander takes up the model of serial production to convey his own vision of history which, like Ford's, is exposed by Powers as a myth. Ford's notion of the series implied that it was necessarily oriented, that it was a synonym for progress, and that it was incremental. On the assembly-line, the addition of each element makes sense in the end, as it culminates in the perfect object, the Model T, which will in turns be reproduced endlessly. Sander removes from the series the notion that it is oriented. The individual is an entryway for him to explore the different social types in Weimar Germany and he substitutes Ford's notion of linear and continuous progress for a tableau of Germany in the 1920s. Olivier Lugon accounts for Sander's synchronic project in Le Style Documentaire: according to him, Sander tackles one of the preoccupations of Weimar Germany, which is the standardization of individuals in the modern world. For the Left, mechanical uniformity signifies the alienation of workers in capitalist societies; for the rest, it is a sign of the decline of Western societies (Lugon 271). As for Sander himself, he likens his own project with a mosaic, the elements of which can only be understood when put in relation with one another. The photographer's intent is thus at once sociological, artistic, and political. It is a form of comparative photography that calls into question class structures at the same time as it shows them. There are seven sections in Sander's Men of the Twentieth Century: the farmer, the skilled tradesman, the woman, classes and professions, the artist, the city, the last people. The order of Sander's work, far from mirroring any hierarchy, intends to be a faithful cross-section of the society of his time and conveys to the subjects what Susan Sontag calls "dignity by juxtaposition" (Sontag 62) as they are all photographed in the same frontal way, in flat light, whatever their attributes and their social statuses. The last section, entitled "The Ill, the Insane and the Disabled," deals another severe blow to a meliorist conception of history, since it shows what Powers calls "the uglier face of humanity" (39), or the "terrible new categories of the time" (41). Powers emphasizes the scientific approach at the root of Sander's attempt: on his first encounter with the three young men, he is described as a bicyclist, who "continues to look from one younger face to the other, with all the attention and dispassion of a botanist engaged in species identification and nomenclature" (26). Not only is Sander's patient addition of portraits reminiscent of botanical taxonomy, it also bears witness to the influence of sociology on art at the beginning of the 20th century, and more specifically of its influence on photography. Sander's approach is in keeping with that of the Cologne Group of Progressive Artists, which he joined in the early twenties. Its members evolved an art both figurative and constructivist that was supposed to offer a reading of social structures and power balances through simplified compositions. According to Olivier Lugon, the serial form allows the photographer to show that there is a pre-existing order in the photographed objects that does not depend on him and must be identified, although the artist's presence is reasserted in the editing of the collection of photographs. By dissecting society, Sander aims at shedding light on it as a whole. Indeed, Sander's pictures are not identity photographs: all the subjects are photographed in the same frontal way with the attributes of their trades, the setting and subject's gestures are arranged by the photographer although the latter's 
intervention is as unobtrusive as possible. Such systematic approach gives the pictures a generic quality. The narrator calls Sander's attempt to embrace and exhaust the visible world a "hopelessly anachronistic cataloguing through the general disillusionment that followed the First War" (45). Following the narrator's logic, such "anachronism" is to be understood on two accounts: the project claims to be exhaustive and to remove the presence of the photographer as much as possible in order to foreground the object, at a time when it was long established that "to see an object from a distance is already to act on it, to change it, to be changed" (45). This constructed neutrality is reminiscent of Barthes' considerations about the discourse of history that seems to write itself without the intervention of a historian. According to Barthes, "The historian gathers signifiers rather than facts and organizes them, which is to say that the historian establishes a positive meaning so as to fill the vacancy left by the mere serial order." ${ }^{3}$ The historical discourse pretends to put the signifier on a par with reality, dispensing with the middle term of the signified. Instead of showing the process of signification that underlies any kind of discourse, the historical discourse attempts to confuse the signified with the referent, thus claiming to express reality and concealing the fact that the referent is but an unformulated signified. Similarly, Sander seems to erase the process of signification from his pictures, "sanding" them in a way as he claims to forego any beautification of reality in order to deliver the undisguised truth to the viewers. Yet the narrator writes that "his family tells of how Sander would chase down an interesting face until the harassed individual threatened the police if not left alone" (45). The adjective "interesting" can only be understood comparatively, and the choice of the interesting face is of course an act of signification. Sander's catalogue reminds Peter, one of the three farmers in the picture, of an impossibly precise map of an unknown terrain. But "a map of one inch to the inch, which cannot be spread without covering the countryside, shows nothing that the place itself does not show just as well" (339). Such a map would in fact dispense with the process of representation, it would be closer to what Deleuze calls a tracing in Mille Plateaux: while the map is open and infinitely connectable, subject to constant modifications and offering multiple entryways, the tracing is the repetition of the same (Deleuze 18). That is what a "map covering the countryside" would amount to: it would be perfectly isomorphic, and would therefore do away with representation. The series, taken by Sander as a model of precision and thoroughness inasmuch as accumulation corrects the contingency inherent in individual pictures, allows the photographer to conceal the processes of representation and signification in order to be perfectly loyal to the "face of his time."

While Ford's series is oriented towards the future, Sander's seems to bring time to a standstill: "Only through the retrospective eyes of a photographer could he embrace the mechanical progress of the times," says the unnamed narrator (116). The collision between a nostalgic force that flows from the present to the past (the retrospective gaze) and the unfolding of mechanical progress (from the past towards the present, or the present towards the future) calls into question the doctrine of endless perfectibility at the root of Ford's welfare capitalism. It is as if progress were frames in a retrospective gaze that froze its ineluctable advance: the all-embracing gaze of the photographer turns the march of time into a tableau, thus undercutting the sweeping enthusiasm of Positivism. Of course, according to the narrator, Sander's hubristic project of paradoxically doing away with the temporal dimension through the systematic exhaustion of the visible was bound to fail: 
Sander's camera could no more exhaustively document Man of the Twentieth Century than a mechanical planetarium can exhaust the night stars. Yet his work completes itself in failure. The shattered, overambitious, unfinished work seems the best possible vehicle for its indemonstrable subject. (43)

10 The series indeed at first seems to be an incremental process: Sander says about photography that it is "like a mosaic in that it coheres into a synthetic image only as it can be accumulated" (letter to Peter Abelen, January 16th, 1951). Yet the world is always beyond the catalogue and Powers suggests that the series is the best way to reveal how ungraspable the world is:

From integrations over tens of thousands of mechanically reproduced prints, extant, maliciously destroyed, or never taken, emerges a sitter by turns willing, self-destructive, reticent, demure, but never, not even in the sum of its unsummable parts, not through naming and categorizing and endless, industrious compilation, never, ultimately, catchable. This incomplete reference book is the most accurate. (43-44)

11 It is as if, instead of being incremental, the series were disintegrating as it is being completed: each new element unsettles the architecture of the whole as it is being added, each new sitter undermines the "type" that the photographer is trying to build, insofar as the sitter adds to the multiplicity of the representatives of a type, and therefore saps the mere notion of type by introducing slight variation. The project of a series of photographs intended to draw an accurate portrait of society bears its own contradiction: it attempts at being asymptotic, yet each new element redefines what comes before. The systematization of Sander's work is precisely the cause of its indefiniteness, of its "failure" but also of its "accuracy" and success. Sander's series is unmade as it is being made and somehow invents a new photographic kinship between the mutable features of the "face of our time" and its own inconclusiveness. The enumeration of adjectives fleshes out the botanist's ambition: through endless compilation, a "type" might emerge. Yet such a type never appears: the first sentence is constantly deferring its own closure, and it closes on what can "never, not even, not even in the sum of its unsummable parts" be seized: the "catchable" sitter. What remains in the end is an accumulation of individuals. The accumulations and amplifications in this sentence only add to the opacity of the object of the photographer's quest, as if the object (the sitter) could be divided ad infinitum, since he is in turns "willing, self-destructive, reticent, demure" and therefore impossible to document exhaustively. On the other hand, the plastic quality of the sentence bespeaks the openness of Powers' prose to the mutable features of the "face of our time": it is as if Powers' discourse redeemed Sander's failure to be exhaustive, by the poetical revealing of the secret correspondences between the photographer's inconclusive series and the constant alterations of the object he was trying to seize. In a way, inconclusiveness is showed to be accurate.

12 The neutral thoroughness of the photographer, or of the historian, is thus the myth Sander's series both constructs and dismisses. Such failure allows him to "blunder against and inadvertently help uncover the principal truth of the century: that viewer and viewed are fused into an indivisible whole. To see an object from a distance is already to act on it, to change it" (45). In Powers' fictions, the artifact, just like the historical event, comes into existence only when colliding against an observer's gaze. 
Such a moment of shock is called "the instant of aha" by Powers, and it is through this unexpected collision ${ }^{4}$ that the work of art appears as three-dimensional, or history exists as something else than ideological discourse.

\section{Stepping out of the series: Powers' solid geometry}

13 The paradigm of the series maintains a model of linearity and sequence that Powers calls into question, as he substitutes simultaneity for succession and intersections and conjunctions of planes for the plane geometry of the series. Indeed Powers' vision of the artifact as well as of the historical event is often evoked in terms of solid geometry. Peter Mays, obsessed by a redhead he saw from his window, eventually falls in love with a waitress in a classy restaurant, Alison. She is required to dress like a Victorian, and reminds a customer of his dead wife:

Krakow had found in her features a hint of the long-ago lost. Yet neither wife nor waitress replaced the other; the old man had set them side by side, variations on an irretrievable original (...). In Alison, Arkady had stumbled on one of those moments of intersection, the plane of the past cutting into the plane of the present and, in the side-by-side juxtaposition of the two, showing the closest hint of the three dimensions of the original template, which preexists the negative and lies outside time. He had read into Alison's face the forward-posted memory of his long-dead wife: they were concurrent. No observation without involvement; no fact without interpretation.

That same intersection of planes, Mays realized, lay behind the compelling look of the farmers on their muddy road. They looked over the photographer at him, at their own continued existence, the face of our time. The same compulsion lay behind his vision of red-hair in the Vets' Parade: a past-inpresent, the side-by-side interference of two worlds. History tips the second view slightly, and parallax combines the two into the full three dimensions of the original image. That original image, the only one possible, was the only and motionless dance. (350)

14 While the logic of the series imposes a progressive unfolding of a narrative, Powers offers an exploration of "the instant of aha," this funny and strange moment when the observer steps out of the observed system and "looks at himself from the vantage point of the object" (208). Simultaneity and displacement lie at the root of this instant. The error of parallax mentioned in the passage turns out to be productive: it gives the observer a new angle of vision that, when combined with another vision of the object, reconstitutes the three-dimensionality of the "original image." That original image, "the only one possible," thus appears as a metaphor and as a construction: Powers exposes its paradoxical nature. The "origin" in this passage is redefined as partly lying in the observer's eye, retrievable only if the observer actively combines two visions: the one the past casts on the present (the three farmers looking at Mays), and the one the present casts on the past. It is therefore the perception of the object at two different times that can result in a vision in three dimensions. In Powers' fiction, such an image, both original and reconstructed, both material and imaginary, both past and present, is invested with an aura of its own; the present perception collides with scenes beaming from elsewhere, uncanny memories or fantasies, thus reactivating the "unique phenomenon of a distance, however close it may be" that was one of Benjamin's many characterizations of the aura of a work of art (Benjamin 278). Such an intersection 
unseats the impression of stability given to reality by a series of photographs that claim to pin down "the face of our time" through a systematic approach, or by the historical discourse as it is described by Barthes.

In this aesthetic of "crossings" offered by Powers, fiction is paramount and constitutes one of the paradoxical dimensions of the accuracy of history. The whole novel is interspersed with polyptotons on the root "cross", from Sander's cross-section of society that "crossed" the Nazi view (since it substitutes a horizontal vision of society for a vertical one), to what the narrator calls the "crucifixion" of the First World War, a recurrence that culminates in Mays' analysis of the response to photography:

Because the process mixes mechanical control with the surprise of light, and because the product mixes technical exactitude with veiling and distortion, the viewer's response is a cross between essayistic firmness-"this, then, the dossier, the facts"-and the invitation of fiction-"What can we make of it?" (250)

Powers invites the reader to acknowledge the fictitious dimension added to history by the observer, not as a liability, but as constitutive of history; not as the cross historiography can't help bearing, but as necessary to the full perception of the historical event. The discourse of fiction thus turns out to have a cognitive function in the novel: it is the dimension without which history remains a flat succession of events, "as if the past were no more than a sum of portraits done in gum arabic and brushed into representative fiction for the lens" (163). The original event, just like the original image, is a cross between what Powers calls "essayistic firmness" and "the invitation of fiction;" such a cross is what restores the unique character of the historical event.

In the same vein, James Hurt has noted that Powers calls for a three-dimensional reading of his novel: the three narrative strands never link up explicitly, except if the reader manages to juxtapose them (Hurt 27). For instance, one of the peasants, Peter Schreck, has a son whose story ends in two different ways: in one version, he ends up as an old man living in the Catskills with his daughter and son-in-law. In the other version, the immigration officer at Ellis Island changes his unpronounceable name ("Peter Hubertus Kinder Schreck Langerson van Maastricht") into Peter Mays. He may or may not be the ancestor of the 1980s' Peter Mays, and it is for the reader to choose between these two "mays." In order for parallax to combine the different strands of the novel, the reader needs to be actively committed in choosing which fictions to combine and how. It is as if the artifact summoned the viewer, called for a specific way of seeing and reading for the reader to make sense of it.

To paraphrase Rancière's title, Politique de la littérature, there is in Powers' novel a politics of the image, which spreads to any artifact including his own book. For Rancière, the politics of literature has nothing to do with the intentions of its authors. It is as if literature itself were "doing" politics, as if the mere form of literature had an effect on what he calls "the partition of the sensitive", that is, a partition of the visible and of the sayable (Rancière 12). Powers argues that Sander's pictures "summon" the viewer: the mere structure of his images, whatever the image, requires the viewer to look for another angle of vision and then combine the two. There is a politics of the image in that the image acts on the viewer on the mode of irruption, shock, as a tear in the fabric of the viewer's time, but it is the layout of the image, not the intention of the photographer, that involves the viewer and somehow obliges him or her to combine 
different angles of vision in order to see the object. The narrator thus comments on the way he now sees Sanders' photograph:

Mrs Schreck's involvement with the photograph forever changed it for me by laying alongside the factual image and interpreted one. One context did not replace the other but existed concurrently, like the two views needed to create an illusion of depth in a stereoscope. (...) With two slightly different views of the photo-the essayistic and the imagined-side-by-side, I needed only the stereopticon itself to bring the image into fleshy threedimensionality. Walking home through the drifts in the dark, I began to imagine what shape that machine might take. I saw the thin film of the image spreading out in two directions, back through the past, through catastrophe, to that idyllic day that had brought the taker and subjects together, and forward in time until the product of that day crossed the path of one who, like me, took on the obligation of seeing. (334) simultaneous vision, combining "the essayistic" and "the imagined." It is not the systematic logic of the series that will lead to a vision of the whole, but the intersection of the factual image and the interpreted one. For the viewer to set the two side by side, the agency of a third term (here Mrs Schreck), is necessary. The aesthetic shock thus inevitably results in an encounter with what Powers calls "the other fellow" (382), the one who will supply the missing angle. While the photographic series implies a continuous and incremental mode of viewing, Powers invents a disjunctive mode of seeing and reading in which the artifact can appear only as a result of a combination of angles or a crossing of planes: the three strands of the novel are as many intersecting planes if the reader chooses to have them intersect, and it is in those moments that the novel coheres as a whole.

\section{Conclusion}

Ford's and Sander's series thus tell us about the limits of certain discourses about history, namely that of Positivism and that of objective historiography. In order to read the historical event as well as the artifact, Powers does away with the linearity implied by the series and evolves a model of seeing based on simultaneity and intersection. The "original object, the only possible one," be it a picture, an event, or a book, turns out to be out of time-it appears at the "instant of aha" when the past and the present collide -and constructed, since it calls for the combination of two angles of vision in order to be seen.

The novel ends with the narrator reaching out for "that most elusive, universal, persistent quantity, always in need of foreign aid, the Other Fellow" (352). Those last words are obviously reminiscent of the motto engraved on Ford's coins, "help the other fellow." But while Ford's injunction betrayed a naive and individualistic vision of history and humanism, it is as if these last words appeared as a natural consequence of the aesthetic program unfolding in the book: seeing means getting involved, observing a system or an artifact amounts to changing it, and the reaching out for the other fellow has little to do with psychology. The narrator's concern for "the other fellow" is thus the consequence of the act performed by the form of the artifact: only the other fellow can provide the missing angle of vision.

Transatlantica, 2 | 2009 


\section{BIBLIOGRAPHIE}

BARTHES, Roland, « Le Discours de l'histoire », in Oeuvres complètes (Paris : Seuil, 1993).

BENJAMIN, Walter, « L'œuvre d'art à l'ère de sa reproductibilité technique », in CEuvres Complètes

(Paris : Gallimard, 2000).

The Work of Art in the Age of Mechanical Reproduction (1935). http://www.marxists.org/reference/ subject/philosophy/works/ge/benjamin.htm.

CARLYLE, Thomas, On Heroes, Hero-worship and the Heroic in History (London: Cassel, 1894).

DELEUZE, Gilles, GUATTARI, Félix, Mille Plateaux (Paris : Minuit, 1989).

HURT, James, "Narrative Powers: Richard Powers as storyteller", Review of Contemporary Fiction $28: 3,24-41$.

LUGON, Olivier, Le Style documentaire, d'August Sander à Walker Evans, 1920-1945 (Paris:Macula, 2001)

POWERS, Richard, Three Farmers on their Way to a Dance (New York: Harper Collins, 1985).

RANCIERE, Jacques, Politique de la littérature (Paris : Galilée, 2007).

SANDER, August, Hommes du vingtième siècle (Paris : Hachette, 1981).

SONTAG, Susan, On Photography (New York: Farrar, Strauss, and Giroux, 1978).

\section{NOTES}

1. «La plupart des critiques de la Neue Sachlichkeit associent, dans leur appel au dépassement du fragment, l'exigence de la systématisation à celle de la défocalisation. Au bout du compte, ce qu'ils reprochent à la Nouvelle Objectivité, c'est d'en faire trop et pas assez. Trop dans la forme, où les savantes découpes en plan rapproché ne seraient que la version moderne d'une photographie décorative encore proche du pictorialisme [...]. Mais en même temps, pas assez dans la mesure où le photographe ne s'appliquerait aucunement à construire un sens à partir de ces fragments accumulés ». LUGON Olivier, Le Style documentaire: d'August Sander à Walker Evans, 1920-1945. (Paris : Macula, 2001), 62.

2. Chapter 10, "Flivvership", is entirely devoted to Ford and Sander ("Both Ford and Sander escaped through the machine, though neither did so completely" [116]), while chapter 19, "The Cheap and Accessible Print", explores the theories about the aura of the work of art Walter Benjamin develops in The Work of Art in the Age of Mechanical Reproduction (1935). The full text can be read on http://www.marxists.org/reference/subject/philosophy/works/ge/benjamin.htm.

3. «L'historien est celui qui rassemble moins des faits que des signifiants et les relate, c'est-àdire les organise afin d'établir un sens positif et de combler le vide de la pure série. » BARTHES Roland, "Le discours de l'histoire", in Informations sur les sciences sociales, VI, n.4, Septembre 1967. (Euvres complètes, 417-427)

4. One of the characters attempts to define this moment: "Puzzles always involve some moment of insight-the instant of aha. The solution comes in a flash, all at once, so simple and so obvious you wonder why you couldn't see it before. But seeing the answer requires jumping out from under bad assumptions." (TF, 151) 


\section{RÉSUMÉS}

Three Farmers on their Way to a Dance, titre d'une photographie qu'August Sander prit en 1914, hante le roman éponyme de Richard Powers. Cette photographie faisait partie d'un projet plus vaste, intitulé « Hommes du vingtième siècle » par Sander qui entendait dresser un inventaire des habitants de sa province natale, le Westerwald. Sander composa ainsi un catalogue de plus de 600 photos d'Allemands de tous types, dont il fit plus tard paraître une partie sous le nom de Visage de notre temps. Dans le roman de Richard Powers, le motif de la série se déploie entre les pôles incarnés par Henry Ford et August Sander, dont les séries de voitures et de photographies deviennent la métaphore du modernisme en marche et des fictions que les deux personnages élaborent sur l'histoire. Nous montrerons dans cet article comment le roman de Powers met au jour ces fictions et en quoi celles-ci consistent; la prose de Powers s'échappe quant à elle de la linéarité imposée par la série pour élaborer une vision «en trois dimensions " de l'événement historique et de l'œuvre d'art, qui ne peut naître que de l'intersection de ce que Powers appelle « la fermeté de l'essai » et de l' « invitation à la fiction ».

Three Farmers on their Way to a Dance is both the title of Richard Powers' novel and of August Sander's 1914 photograph whose haunting influence the book explores. The photograph itself was part of a larger project, "Man of the Twentieth Century," in which Sander attempted to document the people of his native Westerwald. By photographing men and women from all walks of life, Sander thus created a typological catalogue of more than 600 photos of the German people, a part of which was later published in his book Face of our Time. Powers' novel traces the motif of the series through the figures of August Sander and Henry Ford, as their series of photographs and series of cars serve to metaphorise both the advent of modernism and the fictions the two characters build about history. This article intends to show how Powers' novel uncovers the stories about history that underlie Ford's and Sander's series. Yet the paradigm of the series maintains a linearity Powers' prose foregoes: the historical event, just like the artifact, is to be perceived in terms of solid geometry and intersection of planes, a cross between "essayistic firmness" and "the invitation of fiction" that result in a three-dimensional object which the series fails to create.

\section{INDEX}

Mots-clés : Sander, Ford, Powers, série, histoire, photographie

Keywords : Sander, Ford, Powers, series, history, photography

\section{AUTEUR}

\section{FLORA VALADIÉ}

Université Paris III 